\title{
IMPACT OF HOMESTEAD AGRO-FORESTRY ON SUSTAINING LIVELIHOODS OF RURAL POOR IN MYMENSINGH DISTRICT OF BANGLADESH
}

\author{
Nasrin Jahan ${ }^{1}$, M. H. A. Rashid, Tasnimun Jinan ${ }^{2}$ and S. Islam ${ }^{3}$ \\ Department of Agricultural Economics, Bangladesh Agricultural University \\ Mymensingh-2202, Bangladesh
}

\begin{abstract}
This study determines the impact of homestead agro-forestry on livelihood of rural households in Mymensingh district. In total 100 homestead agro-forestry practicing farmers from three upazilas namely Mymensingh Sadar, Bhaluka and Muktagachha of Mymensingh district were randomly selected for this study following a purposive sampling technique. Analysis was done considering the pre (before) and post (after) homestead agro-forestry practicing condition of farmers. The major findings of the study showed that per hectare net returns for vegetables and fruits cultivation were Tk. 6,703.62 and Tk. 14,532.61 respectively considering all farms. On an average, the contribution of vegetables and fruits in total homestead income was 20.23 per cent in before and 22.46 per cent in the after homestead agro-forestry practicing situation indicating enough potentiality to generate income from homestead agro-forestry. It was found that vegetables cultivation was much better for small farmers compared to medium and large farmers. For fruits and vegetables enterprises, the performance of large farmers was better than small and medium farmers. Large farmers were more efficient than medium and small category in case of fruit production. Most of the variables included in the Cobb-Douglas production function model had significant impact on homestead agro-forestry. The study revealed that homestead agro-forestry had positive impact on improving the status of rural households and women empowerment.
\end{abstract}

Key words : Homestead, Agro-forestry, Livelihood

\section{INTRODUCTION}

Bangladesh possesses a glorious tradition of agro-forestry system practiced by its farming communities. It has so long been centered on the farmer's unique understanding of growing crops, rearing livestock and fishes and raising different varieties of trees and plants in and around homestead. In Bangladesh the forest area is very far away from its target. The government forest area is decreasing with an increasing trend. To mitigate the need of fuel, food trees are cut to make different commodities, thus the forests are

\footnotetext{
1-3 Ex-post graduate student, Department of Agricultural Economics, Bangladesh Agricultural University, Mymensingh-2202, Bangladesh

2 Ex-post graduate student, Department of Agricultural Finance, Bangladesh Agricultural

University, Mymensingh-2202, Bangladesh
} 
decreasing. It is agro-forestry system which can prevent the deforestation and can increase the rate of forestation.

Agro-forestry, the integration of tree and crop or vegetable on the same area of land is a promising production system for maximizing yield (Nair 1990). In agro-forestry system interaction between trees and crops or animals is the heart because sharing of the common resources by different species is the common phenomenon. Among different agro-forestry system homestead agro-forestry is one of the oldest and potential systems.

Homestead agro-forestry plays a vital role in the economy of Bangladesh. Trees and other woody species grown in the homesteads are significant sources of food, fodder, fuel wood and timber. Most of the vegetables produced and consumed in the country are coming from the homesteads. Trees in the homesteads, often called, "homestead forests", play an important role in rural economy as well as national economy of Bangladesh. They provide cash during ceremonies, economic hardships and many other occasions such as marriage, school expenses of children and buying land and other assets. Considering the excessive deforestation in Bangladesh, the homestead agro-forestry system needs to be strengthened. Unfortunately the homestead forests are under increasing pressure of exploitation due to the growing population. It has been estimated that $10 \%$ of the standing volume of wood on homestead is removed every year (Abedin and Quddus, 1988).

Homestead agro-forestry improves the socio-economic condition of the farmers by increasing profitability, sustainability and crop security through balanced soil utilization and fertility preservation. It turns to be a constant source of income. If crop fails farmers may get their income from trees. So it bears no risk for the farmers. It makes environment favorable for precipitation, increase humidity and minimize the loss of water through transpiration and keep the microenvironment colder by absorbing water from deep soil level (Haque 1996)

A substantial number of studies have been undertaken home and abroad (Kumar 2006; Momen et al. 2006; Alam et al. 2005; Tewari et al. 2003; Aurangozeb 2002; Nahar 2000; Begum 1998; Mazher 1996; Rahman 1995) addressing the socioeconomic and environmental issues of homestead agro-forestry. The present study is a modest attempt to determine the overall contribution of homestead agro-forestry in rural development

taking into account the activities of cultivation of homestead vegetables and cultivation of fruit trees.

\section{MATERIALS AND METHODS}

\section{The data and field survey}

Keeping in view the objectives of the study, three upazilas namely Mymensingh sadar, Bhaluka and Muktagachha from Mymensingh district were randomly selected for the study. In total, 100 homestead agro-forestry practicing farmers of which 78 small, 15 medium and 7 large farmers were selected and interviewed. A well structured 
questionnaire with open-ended and closed ended questions was used to record necessary information from the respondents. Data were collected during February to March 2008.

\section{Data entry, processing and analysis}

A data base was developed using the Microsoft Excel computer package. Different database files were designed to enter data on various aspects, each file with a common field for the household/respondent identification number. Then the survey data were analyzed to obtain summaries, averages, counts, maxima, minima and standard deviations of the important data pertaining to farm families. The data so entered in Microsoft Excel, were then transferred to another computer package SPSS 11.5 to estimate the functional model.

\section{Analytical technique}

To calculate the gross return and to assess the profitability of the concerned homestead products, the following equations were used.

$\mathrm{GR}_{\mathrm{i}}=\sum_{\mathrm{i}=1}^{\mathrm{n}} \mathrm{Q}_{\mathrm{mi}} \mathrm{P}_{\mathrm{mi}}$

Where,

$\mathrm{GRi}=$ gross return from ith product $(\mathrm{Tk} / \mathrm{ha})$

$\mathrm{Q}_{\mathrm{mi}}=$ quantity of the ith product

$\mathrm{P}_{\mathrm{mi}}=$ average price of the ith product

$\mathrm{i}=1,2$ - - $\mathrm{n}$ crops grown in the study area

Farmers who reported their returns in total value were added as

$\mathrm{Q}_{\mathrm{mi}} \times \mathrm{P}_{\mathrm{mi}}$ (Quantity multiplied by price).

Net return, NRi $=\sum_{i=1}^{n} Q_{m i} P_{m i}+\sum_{i=1}^{n} Q_{b i} P_{b i}-\sum_{i=1}^{n} X_{i} P_{x i}-\sum_{i=1}^{n} H X_{i} P_{h x i}$

Where,

$\mathrm{NRi}=$ net return of ith crop $(\mathrm{Tk} / \mathrm{ha})$;

$\mathrm{X}_{\mathrm{i}}=$ quantity of input of the ith purchased variable;

$P_{x i}=$ per unit price of ith purchased variable input $(\mathrm{Tk} / \mathrm{kg})$;

$\mathrm{HXi}=$ quantity of home supplied variable input;

$P_{\text {hxi }}=$ price of ith home supplied variable input;

$\mathrm{i}=1,2$ - - $\mathrm{n}$ factors used in the homestead agro-forestry;

$\mathrm{Q}_{\mathrm{mi}}=$ quantity of the ith product;

$\mathrm{P}_{\mathrm{mi}}=$ average price of the ith product;

$\mathrm{Q}_{\mathrm{bi}}=$ quantity of the ith by-product $(\mathrm{kg} / \mathrm{ha})$; and

$\mathrm{P}_{\mathrm{bi}}=$ price of the ith by-product.

Functional analysis was also employed to estimate the effects of individual inputs used and other related factors of homestead agro-forestry production with the help of the following Cobb-Douglas production function model.

$$
\mathrm{Y}=\mathrm{a} \mathrm{X}^{\mathrm{b} 1} \mathrm{X}_{2}^{\mathrm{b} 2} \mathrm{X}_{3}^{\mathrm{b} 3} \mathrm{X}^{\mathrm{b4}} \mathrm{X}_{5}^{\mathrm{b} 5} \mathrm{X}_{6}^{\mathrm{b} 6} \mathrm{e}^{\mathrm{ui}}
$$


The alternative form of Cobb-Douglas production function can be estimated using OLS (Ordinary Least Squares) methods as:

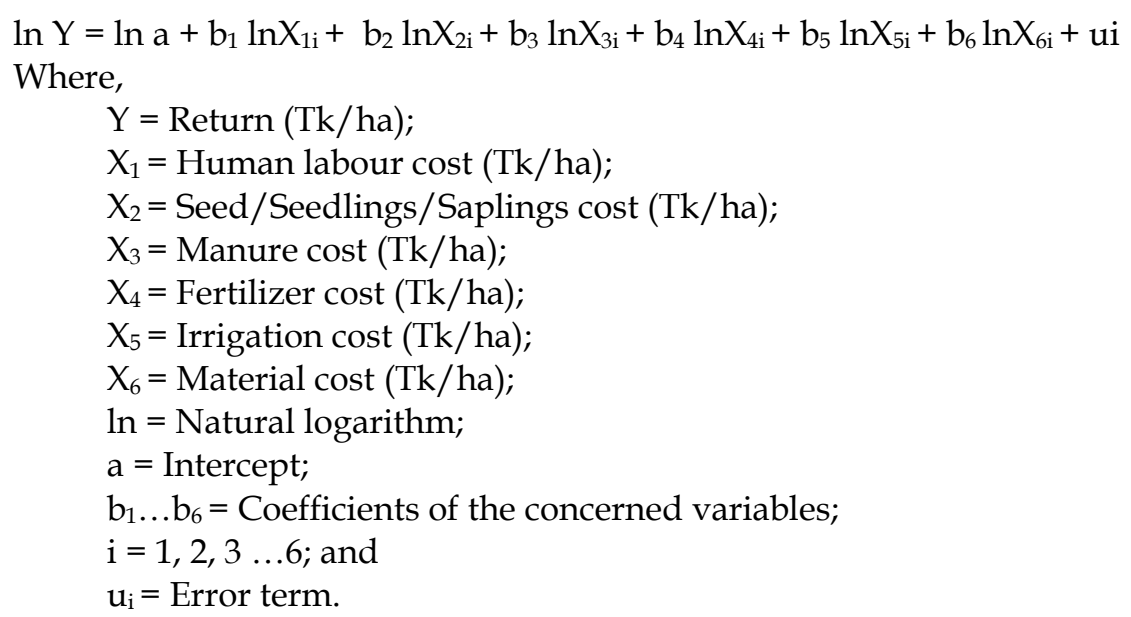

\section{RESULTS AND DISCUSSION}

\section{Cost of vegetables production}

The production costs of vegetables included the cost of seeds/seedlings, manure, fertilizer, irrigation, material cost and labour. The production costs of vegetables are presented in Table 1 on the basis of all farmer categories. Per hectare cost of all vegetables production was estimated at Tk.8520.26 for all farms. The small farms were not capable to use the hired labour rather they used their family labour for vegetables production.

\section{Cost of homestead fruits}

The homestead fruits in the study area were mango, jackfruit, banana, guava, coconut, betel nut and others (Papaya and lemon). The cost items included the costs of seed/saplings, manure/fertilizer, material cost and labour cost in homestead fruits production. Table 2 show that per hectare cost was estimated Tk. 19439.37 for all farms. Surprisingly large farmers used more hired labour compared to other categories of farmers. Thus, the study implied an opportunity of the utilization of idle family labour in the homestead agro-forestry by the small farmers.

\section{Returns from homestead vegetables}

It is evident from Table 3 that variable cost (Tk. 10, 377.08), gross return (Tk. 19,970.88), and net return (Tk. 9,593.80) was the highest in the case of large farms followed by small and medium farms. The net return was found satisfactory for the small and medium farmers. The returns over per Taka investment clarify the efficiency in homestead vegetables production of the respective farms. 
Table 1. Per hectare cost (Tk) of homestead vegetables for all categories of farm

\begin{tabular}{|c|c|c|c|c|c|c|c|c|c|}
\hline $\begin{array}{l}\text { Cost } \\
\text { items }\end{array}$ & $\begin{array}{l}\text { Caulif } \\
\text { lower }\end{array}$ & Radish & $\begin{array}{l}\text { Snake } \\
\text { gourd }\end{array}$ & $\begin{array}{c}\text { Red } \\
\text { amaranth }\end{array}$ & Tomato & $\begin{array}{l}\text { Bottle } \\
\text { gourd }\end{array}$ & Okra & $\begin{array}{c}\text { Others (Chilli, } \\
\text { bean, etc.) }\end{array}$ & Total \\
\hline $\begin{array}{l}\text { Seed/ } \\
\text { Seedlings }\end{array}$ & 193.22 & 54.86 & 100.15 & 45.54 & 184.46 & 77.31 & 64.40 & 147.32 & $\begin{array}{l}867.26 \\
(10.18)\end{array}$ \\
\hline Manure & 72.22 & 67.08 & 70.07 & 76.22 & 80.65 & 95.19 & 94.05 & 185.35 & $\begin{array}{c}740.83 \\
(8.69)\end{array}$ \\
\hline Fertilizer & 88.61 & 88.93 & 66.99 & 43.99 & 92.90 & 74.76 & 95.68 & 158.49 & $\begin{array}{c}710.35 \\
(8.34)\end{array}$ \\
\hline $\begin{array}{l}\text { Material } \\
\text { cost }\end{array}$ & 150.95 & 220.61 & 95.32 & 93.50 & 147.08 & 280.68 & 196.87 & 214.52 & $\begin{array}{c}1399.53 \\
(16.43)\end{array}$ \\
\hline $\begin{array}{l}\text { Labour } \\
\text { cost }\end{array}$ & 398.57 & 713.84 & 553.58 & 513.70 & 363.71 & 420.49 & 465.66 & 532.31 & $\begin{array}{c}3961.86 \\
(46.49)\end{array}$ \\
\hline $\begin{array}{l}\text { Irrigation } \\
\text { cost }\end{array}$ & - & 420.46 & - & - & 419.97 & - & - & - & $\begin{array}{l}840.43 \\
(9.86) \\
\end{array}$ \\
\hline Total & $\begin{array}{l}903.97 \\
(10.60) \\
\end{array}$ & $\begin{array}{c}1565.78 \\
(18.38) \\
\end{array}$ & $\begin{array}{l}892.28 \\
(10.47) \\
\end{array}$ & $\begin{array}{l}772.95 \\
(9.07) \\
\end{array}$ & $\begin{array}{c}1282.60 \\
(15.05) \\
\end{array}$ & $\begin{array}{l}948.43 \\
(11.13) \\
\end{array}$ & $\begin{array}{l}916.66 \\
(10.76) \\
\end{array}$ & $\begin{array}{c}1327.99 \\
(14.53) \\
\end{array}$ & $\begin{array}{c}8520.26 \\
(100) \\
\end{array}$ \\
\hline
\end{tabular}

Source : Own estimation; Figures within parentheses indicate percentage

Table 2. Per hectare cost (Tk.) of homestead fruits cultivation by all categories of farms

\begin{tabular}{|c|c|c|c|c|c|c|c|c|}
\hline $\begin{array}{l}\text { Cost } \\
\text { items }\end{array}$ & Mango & $\begin{array}{l}\text { Jack } \\
\text { fruits }\end{array}$ & Banana & Guava & Coconut & $\begin{array}{c}\text { Betel } \\
\text { nut }\end{array}$ & $\begin{array}{c}\text { Others (Papaya } \\
\text { and lemon) }\end{array}$ & Total \\
\hline $\begin{array}{l}\text { Seed/ } \\
\text { seedlings }\end{array}$ & 660.27 & 365.21 & 699.69 & 164.62 & 527.19 & 414.56 & 398.33 & $\begin{array}{c}3229.87 \\
(16.61)\end{array}$ \\
\hline $\begin{array}{l}\text { Manure/ } \\
\text { fertilizer }\end{array}$ & 404.97 & 191.99 & 239.43 & 113.95 & 335.73 & 260.82 & 49.74 & $\begin{array}{c}1596.63 \\
(8.21)\end{array}$ \\
\hline $\begin{array}{l}\text { Material } \\
\text { cost }\end{array}$ & 513.34 & 123.70 & 438.53 & 217.12 & 384.73 & 357.39 & 346.86 & $\begin{array}{c}2381.67 \\
(12.25)\end{array}$ \\
\hline $\begin{array}{l}\text { Labour } \\
\text { cost }\end{array}$ & 2050.56 & 1286.67 & 1458.33 & 1300.00 & 1931.67 & 1316.67 & 2887.30 & $\begin{array}{c}12231.20 \\
(62.92)\end{array}$ \\
\hline Total & $\begin{array}{c}3629.14 \\
(18.67)\end{array}$ & $\begin{array}{r}1967.57 \\
(10.12)\end{array}$ & $\begin{array}{c}2835.98 \\
(14.59)\end{array}$ & $\begin{array}{c}1795.69 \\
(9.24)\end{array}$ & $\begin{array}{c}3179.32 \\
(16.36)\end{array}$ & $\begin{array}{c}2349.44 \\
(12.09)\end{array}$ & $3682.23(18.94)$ & $\begin{array}{c}19439.37 \\
(100)\end{array}$ \\
\hline
\end{tabular}

Source : Own estimation; Figures within parentheses indicate percentage

Table 3. Per hectare cost and return (Tk) of homestead vegetables by farm sizes

\begin{tabular}{lcccccc}
\hline Categories of farm & Variable cost & Gross return & Net return & Return over per Tk. investment \\
\hline Small farm & 6664.23 & 12260.00 & 5595.77 & 0.84 \\
Medium farm & 8519.47 & 13440.75 & 4921.28 & 0.58 \\
Large farm & 10377.08 & 19970.88 & 9593.80 & 0.92 \\
All farm & 8520.26 & 15223.88 & 6703.62 & 0.79 \\
\hline
\end{tabular}

Source: Own estimation 


\section{Returns from fruits production}

The gross and net returns from fruits production in the study areas are shown in Table 4. It was evident that the net return from the fruits per household was the highest for large farms (Tk. 25581.79) and the lowest for small farms (Tk. 7777.57). It means that large farmers obtained more return from homestead fruits compared to small farmers. The undiscounted benefit-cost ratios (BCR) suggest that mango, jackfruit, guava, betel nut and other fruits (papaya and lemon) were highly profitable fruits to farmers.

Table 4.Variable cost, gross return, and net return (Tk.) of fruits by farm size groups

\begin{tabular}{|c|c|c|c|c|c|c|c|c|}
\hline Items & Mango & Jack fruits & Banana & Guava & Coconut & $\begin{array}{l}\text { Betel } \\
\text { nut }\end{array}$ & $\begin{array}{c}\text { Others } \\
\text { (Papaya and } \\
\text { lemon) }\end{array}$ & Total \\
\hline \multicolumn{9}{|c|}{ Small farm } \\
\hline $\begin{array}{l}\text { Gross } \\
\text { return }\end{array}$ & 3300.00 & 1400.00 & 4140.00 & 800.00 & 3000.00 & 3500.00 & 1000.00 & 17140.00 \\
\hline $\begin{array}{l}\text { Variable } \\
\text { cost }\end{array}$ & 2128.50 & 619.97 & 3160.87 & 482.19 & 1681.85 & 1797.90 & 691.15 & 10562.43 \\
\hline Net return & 1171.50 & 980.03 & 979.13 & 317.81 & 1318.15 & 1702.10 & 1308.85 & 7777.57 \\
\hline BCR & 1.55 & 2.25 & 1.30 & 1.65 & 1.78 & 1.94 & 1.44 & 1.62 \\
\hline \multicolumn{9}{|c|}{ Medium farm } \\
\hline $\begin{array}{l}\text { Gross } \\
\text { return }\end{array}$ & 8100.00 & 2400.00 & 3636.00 & 1200.00 & 2000.00 & 2500.00 & 2000.00 & 21836.00 \\
\hline $\begin{array}{l}\text { Variable } \\
\text { cost }\end{array}$ & 3845.83 & 1103.16 & 2137.25 & 972.58 & 1422.13 & 1233.29 & 1183.39 & 11897.63 \\
\hline Net return & 4254.17 & 1296.84 & 1498.75 & 227.42 & 577.87 & 1266.71 & 816.61 & 9938.37 \\
\hline BCR & 2.10 & 2.17 & 1.70 & 1.23 & 1.40 & 2.02 & 1.69 & 1.83 \\
\hline \multicolumn{9}{|c|}{ Large farm } \\
\hline $\begin{array}{l}\text { Gross } \\
\text { return }\end{array}$ & 7200.00 & 10000.00 & 5040.00 & 7200.00 & 9000.00 & 8000.00 & 16500.00 & 62940.00 \\
\hline $\begin{array}{l}\text { Variable } \\
\text { cost }\end{array}$ & 5413.08 & 4479.60 & 3409.81 & 4032.28 & 6633.94 & 4067.13 & 9322.37 & 35858.26 \\
\hline Net return & 1786.92 & 5520.40 & 1630.19 & 3167.72 & 2366.06 & 3932.87 & 7177.63 & 25581.79 \\
\hline BCR & 1.33 & 2.23 & 1.47 & 1.78 & 1.35 & 1.96 & 1.76 & 1.75 \\
\hline \multicolumn{9}{|c|}{ All farm } \\
\hline $\begin{array}{l}\text { Gross } \\
\text { return }\end{array}$ & 6200.00 & 4600.00 & 4272.00 & 3066.66 & 4666.66 & 4666.66 & 6500.00 & 33971.98 \\
\hline $\begin{array}{l}\text { Variable } \\
\text { cost }\end{array}$ & 3629.14 & 1967.57 & 2835.98 & 1795.69 & 3179.32 & 2349.44 & 3682.23 & 19439.37 \\
\hline Net return & 2570.86 & 2632.43 & 1436.02 & 1270.97 & 1487.34 & 2317.22 & 2817.77 & 14532.61 \\
\hline BCR & 1.70 & 2.33 & 1.50 & 1.70 & 1.46 & 1.98 & 1.76 & 1.74 \\
\hline
\end{tabular}

Source : Own estimation 


\section{Changes in homestead income and its distribution}

It may be mentioned that the income from the different sources represented neither gross nor net returns. Only the cash expenses were deducted from the gross return from individual items. The total homestead income from different sources was the highest for large farms compared to small and medium farms. But income from vegetables and fruits was the highest for small farms compared to medium and large farms. Table 5 showing returns from vegetables and fruits, crops, livestock and poultry, business, service and others. Results indicate that the large farms earned more from crops, while the small farms earned more from the vegetables and fruits production. Thus, it may be concluded from the above findings that the government and non-government organizations (NGOs) should give priority for more involvement in vegetables and fruits component which could help for poverty alleviation as well as improved nutrition in-take.

Table 5. Average annual income (Tk.) from different sources by farm size groups

\begin{tabular}{l|c|c|c|c|c|c|c|c}
\hline \multirow{2}{*}{ Items } & \multicolumn{2}{c}{ Small farm } & \multicolumn{2}{c|}{ Medium farm } & \multicolumn{2}{c|}{ Large farm } & \multicolumn{2}{c}{ All farm } \\
\cline { 2 - 9 } & Before & After & Before & After & Before & After & Before & After \\
\hline Vegetables & 7960 & 13373 & 10550 & 14859 & 27840 & 35175 & 15450 & 21135.66 \\
and fruits & $(24.32)$ & $(27.91)$ & $(15.29)$ & $(19.65)$ & $(21.85)$ & $(22.14)$ & $(20.23)$ & $(22.46)$ \\
Crops & 2500 & 4000 & 17360 & 20600 & 45500 & 55000 & 21786.66 & 26533.33 \\
& $(7.46)$ & $(8.35)$ & $(25.17)$ & $(27.24)$ & $(35.72)$ & $(34.63)$ & $(28.52)$ & $(28.19)$ \\
Livestock & - & 500 & 1000 & 1616 & 5000 & 8000 & 2000 & 3372 \\
and poultry & & $(1.04)$ & $(1.45)$ & $(2.14)$ & $(3.93)$ & $(5.04)$ & $(2.62)$ & $(3.58)$ \\
Business & 5370 & 8035 & 25660 & 21000 & 25700 & 30000 & 18910 & 19678.33 \\
& $(16.41)$ & $(16.77)$ & $(37.20)$ & $(27.77)$ & $(20.17)$ & $(18.89)$ & $(24.76)$ & $(20.91)$ \\
Service & 10450 & 13800 & 6840 & 7550 & 12600 & 16000 & 9963.33 & 12450 \\
& $(31.92)$ & $(28.20)$ & $(9.92)$ & $(9.98)$ & $(9.89)$ & $(10.07)$ & $(13.04)$ & $(13.23)$ \\
Others & 6500 & 8200 & 7560 & 10000 & 10750 & 14666 & 8270 & 10955.33 \\
& $(19.71)$ & $(17.11)$ & $(10.96)$ & $(13.22)$ & $(8.44)$ & $(9.23)$ & $(10.83)$ & $(11.64)$ \\
\hline Total & 32730 & 47909 & 68970 & 75627 & 127394 & 158843 & 76379.99 & 94124.32 \\
& $(100)$ & $(100)$ & $(100)$ & $(100)$ & $(100)$ & $(100)$ & $(100)$ & $(100)$ \\
\hline
\end{tabular}

Source : Own estimation; Figures within parentheses indicate percentage

\section{Socio-economic changes occurred among the respondents}

Attempt has been made in the present study to examine the socio-economic changes which might have occurred among the respondents participate in the homestead agroforestry. The measuring scale of the impact of changes in mentioned variables (Table 6) towards practicing homestead agro-forestry thereof, measuring scale was expressed in terms of no change, small change, medium change and highly change. About 29 per cent of the large farmers said that there was highly change of income and 44 per cent of all sample farmers reported there was small change in the scope of family education. But all types of farmers were very much conscious about the adoption of family planning and the percentage of medium change was 45 . The socio-economic changes of the homestead agro-forestry farmers are shown in Table 6 . The results presented in Tables 5 and 6 clearly support that the homestead agro-forestry has positive impact on changes in livelihoods pattern and women empowerment. 


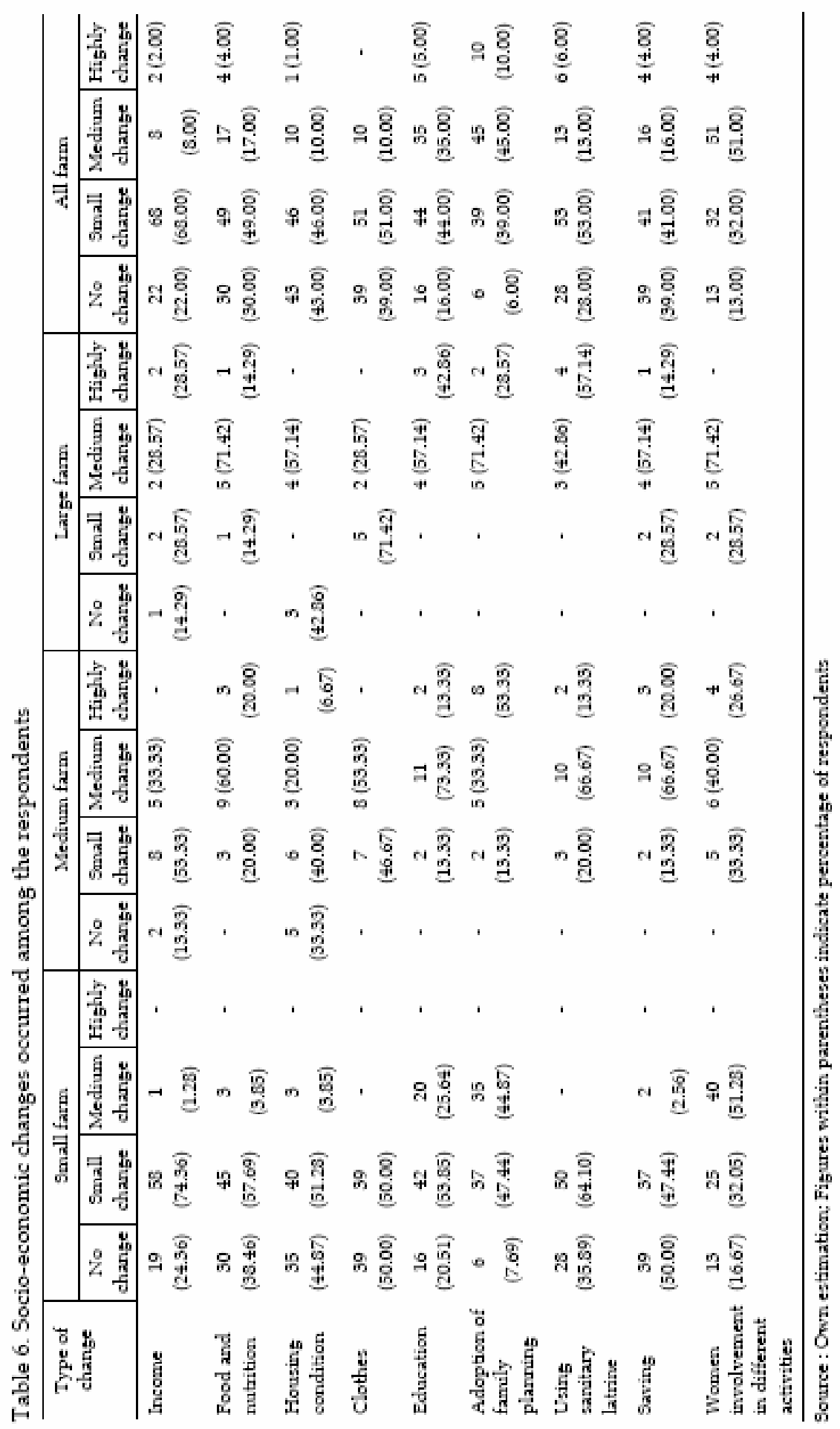




\section{OLS estimates of the cobb-douglas production function}

Table 7. Estimated values of co-efficient and related statistics for production function of log linear regression model

\begin{tabular}{l|cc}
\hline \multirow{2}{*}{ Explanatory variables } & \multicolumn{2}{c}{ Co-efficients } \\
\cline { 2 - 3 } & Vegetables & Fruits \\
\hline Intercept $(\mathrm{a})$ & 3.852 & 3.597 \\
Human labour $\left(\mathrm{X}_{1}\right)$ & $0.271^{*}(0.079560)$ & $0.439^{* *}(0.126686)$ \\
Seed/seedlings/sapling $\left(\mathrm{X}_{2}\right)$ & $0.206^{* * *}(0.0534343)$ & $0.226^{* *}(0.124343)$ \\
Manure $\left(\mathrm{X}_{3}\right)$ & $0.482^{*}(0.03357)$ & - \\
Fertilizer $\left(\mathrm{X}_{4}\right)$ & $-0.05672(0.043072)$ & $0.695^{*}(0.13567)$ \\
Irrigation $\left(\mathrm{X}_{5}\right)$ & $-0.0312(0.016982)$ & - \\
Material cost $\left(\mathrm{X}_{6}\right)$ & $-0.04625(0.043026)$ & $0.155^{\text {*** }}(0.109767)$ \\
$\mathrm{R}^{2}$ & 0.792 & 0.90 \\
Adjusted $\mathrm{R}^{2}$ & 0.790 & 0.89 \\
$\mathrm{~F}$ & 135.87 & 45.879 \\
Return to scale $\left(\sum \mathrm{bi}\right)$ & 0.825 & 1.515 \\
\hline
\end{tabular}

Source : Own estimation; Note: Figures within parentheses indicate standard error

*** Significant at 10 per cent level; ${ }^{* *}$ Significant at 5 per cent level; ${ }^{*}$ Significant at 1 per cent level

It is evident from the Table 7 that applications of inputs can be increased to achieve higher amount of homestead production. The main influencing factors of homestead vegetables and fruits production are human labour, seed/seedlings/saplings, manure, fertilizer, other materials and irrigation. It is evident from Table 7 that, the sensitive factors are fertilizer, irrigation and material cost for vegetables production. It implied that if the sensitive factors are used more, there might be negative effect on production of the respective homestead fruits and vegetables.

\section{CONCLUSIONS}

The findings of the study confirmed that the small farmers are mostly benefited by the homestead agro-forestry such as vegetables and fruits cultivation. It also provides the opportunity of employment for a large number of laborers especially for the women in Bangladesh. After practicing homestead agro-forestry total household income of rural people were increased significantly which enabled them to spend more on basic items such as food, education, clothing, health care and housing compared to before. It indicates that livelihood and standard of living of homestead agro-forestry farmers improved to some extent. Among all farmers were the most beneficiaries of earning income from homestead agro-forestry. However, the farmers having homestead areas need to be motivated and provided with necessary logistic supports to increase production from homesteads area. Short term training programme on modern technique should be provided to make the farmers aware of modern technologies and technique of production. Necessary inputs such as HYV seed/seedlings, fertilizer, insecticides and credit should be available in time. Marketing facilities as well as fair prices of different 
products need to be ensured. Farm women should be encouraged more to participate in homestead agro-forestry as a means of their income generation, stronger voice in family decision making process, etc. Extension services should be provided and training should be given to the rural women by the government and non-government agencies/ organization to encourage the rural women folk for practicing homestead agro-forestry.

\section{REFERENCES}

Abedin, M. Z. and Quddus, M. A. 1988. Household Fuel Situation, Home Gardens and Agroforestry Practices at six agro-ecologically different locations of Bangladesh. In: Abedin et al. 1990. Homestead Plantation and Agro-forestry in Bangladesh. Bangladesh Agric. Res. Inst., Gazipur.

Alam, M. S., Zaman, M. S., Salam, M. A., Bari, M. S. and Hasan, M. A. 2005. Effect of pruning on free height and trunk circumference in five agro-forestry tree species. Rangpur Dinajpur Rural Service (RDRS), Rangpur, Bangladesh. Tropical-Agricultural-Research and Extension. 8:22-27. Kamburupitiya, Srilanka. Dept. of Agricultural Biology, Faculty of Agriculture, University of Ruhuna.

Aurangozeb, M. K. 2002. "Adoption of Integrated Homestead Farming Technologies by the Rural Women in RDRS." M.S. (Ag. Ext. Ed.). Thesis. Dept. of Agric. Ext. Ed., Bangladesh Agricultural University, Mymensingh.

Begum, I.A. (1998), "An Economic Study of Homestead Agro-forestry in a Selected Area of Mymensingh District." M. S. Thesis, Dept. of Agricultural Economics, Bangladesh Agricultural University, Mymensingh.

Haque, M. A. 1996. Homestead Agro-forestry in Bangladesh. In: Agro-forestry in Bangladesh. VFFP, Bangladesh Agricultural University, Mymensingh and SDC, Dhaka. pp. 64-70.

Kumar, B. M. 2006. Dept. of Silviculture and Agro-forestry, college of Forestry, kerala Agricultural University, KAUPO, Thrissur 680656, kerala, India. Journal of Tropical Agriculture, 44(1/2): 1-14. Thrissur, India, kerala Agricultural University.

Mazher, K. 1996. "An Economic Analysis of Homestead Farming in Some Selected Areas of Mymensingh District." M. S. Thesis. Dept. of Agricultural Economics, Bangladesh Agricultural University, Mymensingh.

Momen, R. U., Huda, S. M. S., Hossain, M. K. and Khan, B. M. 2006. Economics of the plant species used in homestead agro-forestry on an off-shore Sandwip Island of Chittagong District, Bangladesh. Institute of Forestry and Environmental Sciences, University of Chittagong, Chittagong 4331, Bangladesh. Journal of Forestry Research. 17 (4): 285-288, 2 Harbin, China: Northeast Forestry University.

Nair, P. K. R. 1993. An Introduction of Agro-forestry Kluwer Academic Publishers, Netherlands.

Rahman, M. H. 1995. Production of Homestead Enterprises Implication on Income and Women's Status. Bangladesh J. Agril. Econ., 18(2): 99-105.

Tewari, J. C., Tripathi, D., Singh, S. P. and Narain, P. 2003. A study of the structure, energy fluxes and emerging trends in traditional central Himalayan Agro-forestry system. Forest-Trees and Livelihoods. 13(1): 17-37. 